\title{
Effect of Body Condition Score of the Dairy Cow on the in vitro Immune Response of Peripheral Blood Mononuclear Cells to Progesterone Stimulation
}

\author{
Hiromichi OHTSUKA ${ }^{1) *}$, Yurie MURASE ${ }^{1)}$, Takaaki ANDO'1), Masayuki KOHIRUIMAKI²), Machiko MUKAI'), \\ Masaaki OIKAWA ${ }^{1)}$, Kiro R PETROVSKI ${ }^{3)}$ and Stephen MORRIS ${ }^{3)}$ \\ ${ }^{1)}$ School of Veterinary Medicine, Kitasato University, Towada, Aomori 034-8628, ${ }^{2)}$ Kohiruimaki Animal Medical Service, Tohoku, \\ Aomori 039-2683, Japan and ${ }^{3)}$ College of Sciences, Massey University, Palmaerston North 4442, New Zealand
}

(Received 29 July 2008/Accepted 21 November 2008)

ABSTRACT. Immune function in cows is closely associated with their physical and hormonal conditions. In order to clarify the relationship between the body condition score (BCS) of lactating dairy cows and the immune response to progesterone $\left(\mathrm{P}_{4}\right)$ in vitro, we examined whether lower BCS in dairy cows affects the responsiveness of peripheral blood mononuclear cells (PBMCs) to $\mathrm{P}_{4}$ added in to culture medium. Forty-two non-pregnant healthy Holstein dairy cows were examined at 61 to 120 days after calving. The cows were divided into the following two groups; Low BCS group $(\mathrm{N}=20)$, which had a BCS of less than 2.25, and a Control group ( $\mathrm{N}=22)$, which had a BCS over 2.75. PBMCs were stimulated with $\mathrm{P}_{4}(1 \mu \mathrm{g} / \mathrm{mL})$ and/or phytohemagglutinin (PHA), and the levels of cytokine mRNA were analyzed. In the Low BCS group, a significantly lower IFN- $\gamma$ level was stimulated by PHA only compared with the Control group. The combination of $\mathrm{P}_{4}$ and PHA significant decreased the IFN- $\gamma / \mathrm{IL}-4$ ratio in the Control group, but this reaction was not found in the Low BCS group. Our data indicated that expression of IFN- $\gamma$ mRNA was basically lower in the low BCS dairy cows and that addition of $\mathrm{P}_{4}$ did not suppress the cellular immune function in these cows. In this study, we observed that $\mathrm{P}_{4}$ reduced the cellular immune response in the adequate BCS cows, whereas immunosuppression by $\mathrm{P}_{4}$ was not found in the PBMCs of the low BCS cows, which already had a lower level of immune function.

KEY WORDS: body condition score, dairy cow, immune function, progesterone.

J. Vet. Med. Sci. 71(5): 549-553, 2009

Mastitis and endometritis are frequently observed in dairy cows, and these diseases affect productivity. Yield and quality of milk decrease in mastitic cows, and reproductive performance declines in cows with endometritis. Deluyker et al. [4] reported that occurrence of clinical mastitis is associated with $5 \%$ milk yield loss and that cows with a mean SCC greater than 245,000 cells/ml over 119 d show a $6.2 \%$ yield loss compared with cows with an SCC of 90,000 cells/ $\mathrm{ml}$ or less. Failure of immune function to prevent bacterial invasion in the mammary gland or uterus is closely related to the occurrence of these infectious diseases [11]. Low body condition score (BCS) is closely associated with morbidity in the dairy cow $[6,20]$, and a higher somatic cell count (SCC) or clinical mastitis is frequently observed in low BCS cows [21].

It is well known that cows with a BCS of less than 2.25 have reduced breeding performance $[5,15]$. Progesterone $\left(\mathrm{P}_{4}\right)$ is important for fertility as demonstrated by the positive correlation between the serum $\mathrm{P}_{4}$ level at the time of artificial insemination and the subsequent conception rate. Therefore, $\mathrm{P}_{4}$ supplementation is used frequently to improve the serum $\mathrm{P}_{4}$ level in order to enhance the reproductive performance of dairy cows with low serum $\mathrm{P}_{4}$ levels, such as lower BCS cows [18]. On the other hand, $\mathrm{P}_{4}$ is well known as one of the hormones that suppresses immune function. Previous studies in the mouse have revealed that $\mathrm{P}_{4}$ directly suppresses $\mathrm{T}$ cell differentiation into Th1 cells but enhances

\footnotetext{
* Correspondence to: Ohtsuka, H., School of Veterinary Medicine, Kitasato University, Towada, Aomori 034-8628, Japan. e-mail:otsuka@vmas.kitasato-u.ac.jp
}

differentiation into IL-10-producing Th2 cells [13]. Therefore, it is possible that $\mathrm{P}_{4}$ also suppresses cellular immune function in cows. However, the effect of $\mathrm{P}_{4}$ on immune function in dairy cows has not been elucidated. We hypothesized that $\mathrm{P}_{4}$ would suppress immune function in dairy cows during the lactating periods and that administration of $\mathrm{P}_{4}$ containing-medicines would severely depresses immune function of cows, especially those with a lower BCS. The present study was carried out to evaluate the relationship between BCS and the in vitro response of PBMCs stimulated with $\mathrm{P}_{4}$ in dairy cows during mid lactation in order to examine the relationship between low BCS and $\mathrm{P}_{4}$ in terms of immune cell function.

\section{MATERIALS AND METHODS}

Forty-two Holstein dairy cows that were 61 to 120 days after calving and kept at 12 dairy farms were used in this study. All cows were housed in tie stall barns. The presence of a corpus luteum was confirmed in all cows by rectal palpation in order to confirm presence of the esterous cycles (non-pregnant). The peak luteal phase was avoided since the serum $\mathrm{P}_{4}$ concentration during this phase can reach over $1 \mathrm{ng} / \mathrm{mL}$. All cows were confirmed to be clinically healthy on the day that blood samples were collected and remained non-pregnant. No periparturient diseases were observed in the cows used in this experiment. The cows were divided into the following two groups; Low BCS group $(\mathrm{N}=20)$, which had a BCS under 2.25 (Scale 0-5) and an average days after calving of $100.6 \pm 4.8$, and a Control group 
( $\mathrm{N}=22)$, which had a BCS over 2.75 and an average days after calving of $96.7 \pm 4.3$.

Blood sampling was performed for each individual animal at 61 to 120 days post-calving; samples were collected into tubes, which contained no anticoagulant, heparin or dipotassium-EDTA. The serum was separated from the blood in the tubes without the use of an anticoagulant and stored at $-30^{\circ} \mathrm{C}$ until analysis. The serum was used to measure total cholesterol and ketone bodies (enzyme assay) and blood urea nitrogen (urease indophenol method). Hematocrit and total white blood cell counts (WBC) were determined with blood collected into dipotassium-EDTA using a blood cell counter (PC607, ERMA, Germany).

Serum $\mathrm{P}_{4}$ concentration was measured by enzyme immunoassay using anti-progesterone (FKA304E, Cosmo Bio Co., Ltd., Tokyo, Japan) as the 1st antibody and goat antirabbit IgG (AP132, Chemicon International, Temecula, CA, U.S.A.) as the 2nd antibody. The P4 assay was performed for all samples at the same time to avoid interassay variations, and the intra-assay coefficient of variation was $4.0 \%$.

Freshly isolated leukocytes were subjected to flow cytometry as described previously [14]. Two $\mathrm{ml}$ of blood samples from the tubes containing dipotassium-EDTA were mixed with $4 \mathrm{ml}$ of $0.83 \%$ ammonium chloride solution to lyse the red blood cells, and the leukocytes were then separated. WBCs $\left(1 \times 10^{6}\right)$ were incubated with monoclonal antibodies prepared in PBS at $4^{\circ} \mathrm{C}$ for $60 \mathrm{~min}$. The primary antibodies and descriptions of the working solutions are presented in Table 1. Two-color flow cytometric analysis was performed with fluorescein isothiocyanate (FITC)-conjugated anti-human CD14 antibody, and phycoerythrin (PE)conjugated Goat-anti-mouse IgG secondary antibody (ICN Biomedicals, Inc., Costa Mesa, CA, U.S.A.) added to PBS for $30 \mathrm{~min}$. Following the second incubation, the samples were twice washed with PBS, and between 10,000 and 20,000 events were collected per condition on a FACScan cytometer (Becton Dickinson, Bedford, MA, U.S.A.); the data were then analyzed using the CellQuest software (Becton Dickinson). The number of each sell population was calculated by multiplication of the percentage by WBC count.

Heparinised blood was used for analysis of cytokine mRNA expression First, $2 \times 10^{6}$ PBMCs in a total volume of $1 \mathrm{~mL}$ of $10 \%$ FCS-RPMI were placed in a 24-well plate and stimulated with phytohemagglutinin (PHA ; Sigma-Aldrich Corporation, St. Louis, MO, U.S.A.; $5 \mu \mathrm{g} / \mathrm{ml}$ ) for $12 \mathrm{hr}$ at $37^{\circ} \mathrm{C}$. After incubation, PBMC pellets were harvested, and the cells were resuspended using TRIzol reagent (Invitrogen, Carlsbad, CA, U.S.A.) to collect RNA from the cells.

Real-time PCR was used to measure the mRNA levels of cytokines as previously described [14]. Two micrograms of total RNA from each sample were used for synthesis of firststrand cDNA with oligo-dT primers (Invitrogen, Carlsbad, CA, U.S.A.) and Superscript II Reverse Transcripts (Invitrogen, Carlsbad, CA, U.S.A.) according to the manufacturer's protocols. Real-time PCR was performed with SYBR Green Master Mix on an ABI prism 7700 Sequence Detector (Applied Biosystems, Foster City, CA, U.S.A.). The target cDNA sequence was specifically amplified using previously designed primers (IL-1, IL-4, IFN- $\gamma$ ) [19]. The melting curve was determined for each PCR product. The comparative threshold cycle number $(2-\Delta \Delta \mathrm{Ct})$ method was used in our analysis. After validation, the experiment demonstrated that the efficiencies of the target and reference ( $\beta$ actin) were approximately equal. The $\mathrm{Ct}$ values define the threshold cycle of PCR, at which amplified products were detected. The results are presented as DDCt values, where $\Delta \Delta \mathrm{Ct}$ is the difference in the threshold cycles for the target and $\beta$-actin is an internal control. Fold changes in expression for the two groups $(\Delta \Delta \mathrm{Ct}$ ) were calculated using the formula $2-{ }^{\Delta \Delta C t}$ as previously described [9].

Statistical analysis was performed using the Student's $t$ test for each parameter in the two groups, and the differences between the groups were considered significant at $P<0.05$. The mean and standard errors of the clinical and laboratory data were calculated.

\section{RESULTS}

Table 2 shows the data obtained from the blood analysis. A significantly higher level of $\beta$-hydroxy butyrate (BHB) was found in the Low BCS group compared with the Control group. There were no marked differences in any other parameters between the two groups. The serum $\mathrm{P}_{4}$ concentration was higher in the Low BCS group compared with that in the Control group, but there was no significant difference between the 2 groups.

The data for the leukocyte populations are shown in Table 3. The numbers of $\mathrm{CD}^{+}, \mathrm{CD}^{+}$and $\mathrm{CD} 8^{+} \mathrm{T}$ cells in the Low BCS group tended to be lower (not statistically significant) compared with those in the Control group. Significantly lower numbers of WC1-N3 ${ }^{+} \mathrm{T}$ cells were found in

Table 1. Antibodies used for immunostaining of peripheral blood mononuclear leukocytes

\begin{tabular}{ccccc}
\hline Antigen & MAb clone & Isotype & Specificity & Source \\
\hline CD3 & MM1A & IgG1 & Pan T cell & VMRD \\
CD4 & CACT138A & IgG1 & Helper/inducer & VMRD \\
CD8 & CACT80C & IgG1 & Cytotoxic & VMRD \\
CD14 & MY4 & IgG2b & Monocyte & Coulter \\
WC1-N3 & CACTB32A & IgG1 & $\gamma \delta$ T-cell receptor & VMRD \\
MHC Class II & CAT82A & IgG1 & Class II major histocompatibility complex & VMRD \\
\hline
\end{tabular}

VMRD=VMRD, Inc. (Pullman, WA, U.S.A).

Coulter=Becman Coulter (Tokyo, Japan).

The original concentration of the MAb solution was $1 \mu \mathrm{g} / \mathrm{ml}$. 
Table 2. Blood parameters and serum progesterone concentrations of the two groups

\begin{tabular}{lcc}
\hline Parameter & Low BCS group $(\mathrm{N}=20)$ & Control group $(\mathrm{N}=22)$ \\
\hline Ht $(\%)$ & $30.9 \pm 0.6$ & $33.1 \pm 0.9$ \\
WBC $\left(\times 10^{2} / \mu l\right)$ & $83.3 \pm 4.4$ & $89.6 \pm 5.0$ \\
T-cho $(\mathrm{mg} / \mathrm{d} l)$ & $222.0 \pm 9.2$ & $220.5 \pm 11.2$ \\
BUN $(\mathrm{mg} / \mathrm{d} l)$ & $14.8 \pm 0.7$ & $13.9 \pm 0.5$ \\
BHB $(\mu \mathrm{mol} / l)$ & $774.5 \pm 62.4$ & $567.6 \pm 39.6^{*}$ \\
$\mathrm{P}_{4}(\mathrm{ng} / \mathrm{m} l)$ & $3.25 \pm 0.66$ & $1.90 \pm 0.50$ \\
\hline
\end{tabular}

These data were analyzed for each individual non-pregnant cow. The asterisk indicates a significant difference between the groups $(\mathrm{p}<0.05$ by Student's $t$-test). The data expressed as means \pm S.E.

the Low BCS group. The other lymphocyte and monocyte numbers did not differ between the two groups (Table 3).

The influence of $\mathrm{P}_{4}$ on the expression of cytokines in PBMCs stimulated with PHA is shown in Fig. 1. The mRNA levels of IL-1, IL-4 and IFN- $\gamma$ in the PBMCs stimulated with PHA alone tended to be lower in the Low BCS group than in the Control group, and a significantly low level of IFN- $\gamma$ was found in the Low BCS group. The mRNA level of IFN- $\gamma$ in the Control group decreased following stimulation with $\mathrm{P}_{4}$. However, this decrease was not observed in the Low BCS group. Moreover, $\mathrm{P}_{4}$ did not appear to have a suppressive effect on IL- 1 and IL-4 mRNA expression in either group. The IFN- $\gamma / \mathrm{IL}-4$ ratio of the Control group decreased significantly in the cultures containing $\mathrm{P}_{4}$ compared with those of the culture with PHA alone, but this did not occur in the Low BCS group.

\section{DISCUSSION}

$\mathrm{P}_{4}$ is essential for the establishment and maintenance of pregnancy, including ovulation and uterine and mammary gland development [10]. The major sources of $\mathrm{P}_{4}$ during pregnancy are the corpus luteum of the ovary and, in many species including humans and rodents, the placenta [24]. $\mathrm{P}_{4}$ favors Th2 cytokine production and reduces the number of Th1 cytokines in immune cells [25]. The current study examined whether the effect of $\mathrm{P}_{4}$ on immune cell responses differs between dairy cows with low BCS and those with a BCS of more than 2.75. Th1 to Th2 cytokines in the Control group that manifested as a decrease in the IFN- $\gamma$ level in isolated PBMCs stimulated with $\mathrm{P}_{4}$, and this was similar to the results of studies with human cells [3]. These results suggested that the PBMCs from dairy cows with adequate BCS were susceptible to $\mathrm{P}_{4}$, but that the PBMCs from the dairy cows with a low BCS were not.

Dairy herds that frequently experience periparturient disease tend to receive a nutritionally poor diet. Depressed cellular immune function, such as low IFN- $\gamma$ levels and low numbers of $\mathrm{CD}^{+} \mathrm{T}$ cells, have been observed in dairy cows fed a poor diet during the periparturient period [14, 26]. Several metabolic stresses in dairy cows, such as malnutrition and disorder of fat metabolism around the time of calving, can result in lower responsiveness of immune cells to stimulations during the lactation period. Subclinical ketosis is frequently observed during the lactation period in dairy herds with poor diets around the time of calving [8]. In the current study, several subsets of $\mathrm{T}$ cell numbers were lower in the Low BCS group. Significantly lower numbers of $\gamma \delta \mathrm{T}$ cells and total T cells were observed in the Low BCS group. The $\gamma \delta \mathrm{T}$ lymphocyte can produce high amounts of IFN- $\gamma$ in response to stimulation with cytokines [17]. Therefore, a decrease in T cell numbers, especially $\gamma \delta$ T lymphocyte might affect cytokine production in Low BCS cows. Our results suggest that the low IFN- $\gamma$ level of the lymphocytes after stimulation with PHA in the Low BCS group might have been due to subclinical ketosis based on the high serum BHB levels in these cows. Ketotic cows tend to have suppressed lymphocyte proliferation because ketone bodies directly suppress lymphocyte blastogenesis stimulated by mitogens in the dairy cow [22]. Therefore, this decreased lymphocyte proliferation is thought to be associated with decreased immune function [2]. Fatty acids play an important role in regulation of immune responses, thus manipulation of dietary lipids affects production of T-cell-derived cytokines in mice [27]. A previous study reported that the increased plasma fatty acid levels in ketosis or starvation might impair immune function by causing changes in lymphocyte metabolism in mitochondria through activation of the caspase cascade [16]. These findings suggested that the lower ability to produce IFN- $\gamma$ in Low BCS cows might enhance the systemic immunosuppression already elicited

Table 3. Peripheral leukocyte populations of the two groups

\begin{tabular}{|c|c|c|}
\hline Cell number & Low BCS group $(\mathrm{N}=20)$ & Control group $(\mathrm{N}=22)$ \\
\hline $\mathrm{CD}^{+}\left(\times 10^{2} / \mu \mathrm{l}\right)$ & $15.0 \pm 1.5$ & $18.0 \pm 2.3$ \\
\hline $\mathrm{CD}^{+}\left(\times 10^{2} / \mu \mathrm{l}\right)$ & $5.8 \pm 0.7$ & $8.0 \pm 1.2$ \\
\hline $\mathrm{CD}^{+}\left(\times 10^{2} / \mu l\right)$ & $3.0 \pm 0.5$ & $3.5 \pm 0.5$ \\
\hline $\mathrm{CD}^{+} / \mathrm{CD}^{+}$ & $2.52 \pm 0.36$ & $2.34 \pm 0.20$ \\
\hline $\mathrm{WC1}^{-\mathrm{N3}^{+}}\left(\times 10^{2} / \mu l\right)$ & $2.0 \pm 0.3$ & $2.9 \pm 0.4^{*}$ \\
\hline MHC class-11 $^{+} \mathrm{CD} 14^{-}\left(\times 10^{2} / \mu \mathrm{l}\right)$ & $11.4 \pm 1.0$ & $10.6 \pm 1.0$ \\
\hline MHC class-11 ${ }^{+} \mathrm{CD} 14^{+}\left(\times 10^{2} / \mu l\right)$ & $4.2 \pm 0.4$ & $3.8 \pm 0.4$ \\
\hline 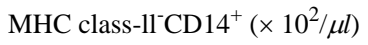 & $2.5 \pm 0.5$ & $4.0 \pm 0.06$ \\
\hline
\end{tabular}

These data were analyzed for each individual non-pregnant cow. The asterisk indicates a significant difference between the groups $(\mathrm{p}<0.05$ by Student's $t$-test). The data expressed as means \pm S.E. 


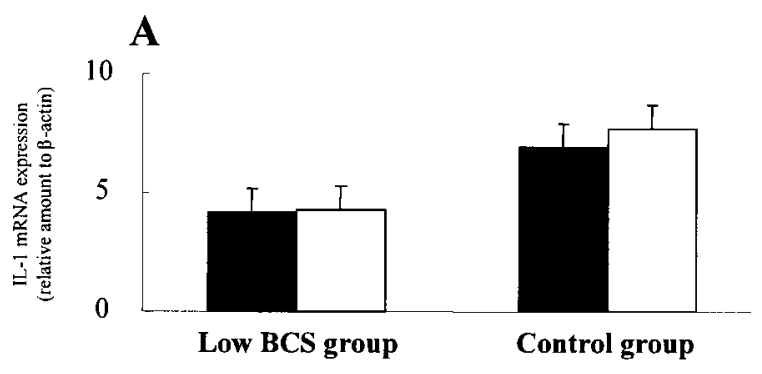

B
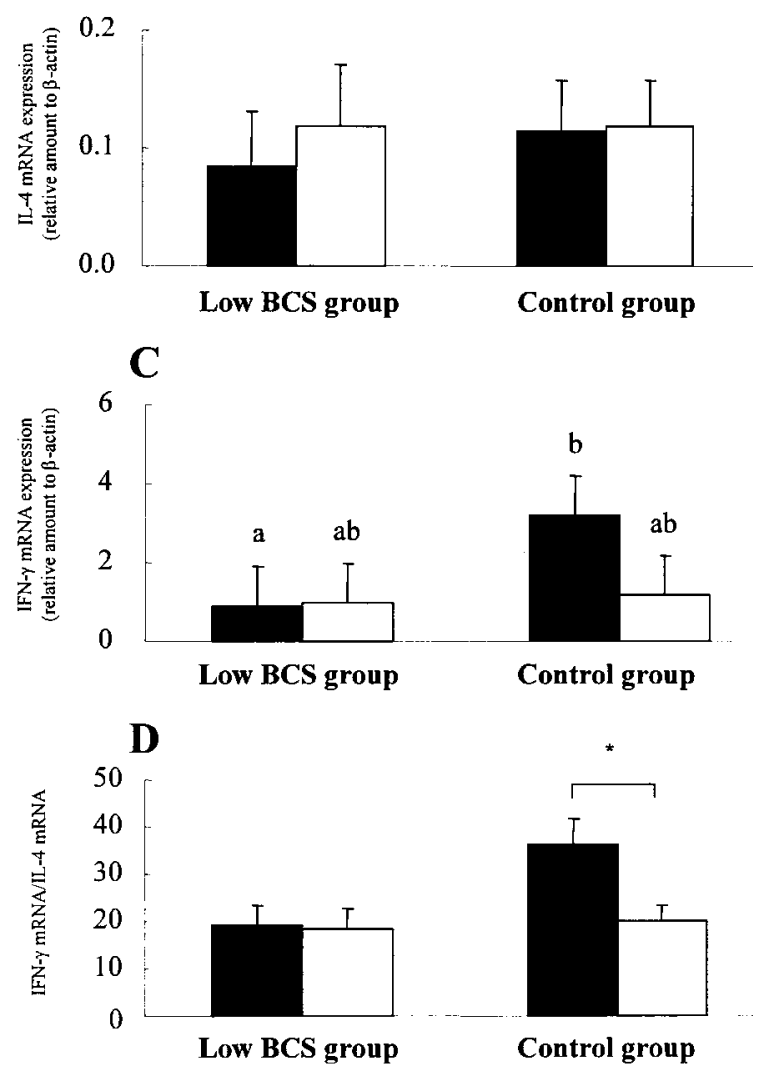

Fig. 1. Cytokine mRNA expressions in PBMCs from the lactating cows of the 2 groups. A. Levels of IL- $1 \bullet$ mRNA. PBMCs were stimulated with either PHA alone $(\square)$ or a combination of PHA and P4 ( $\square$ ). B. Levels of IL-4 mRNA. PBMCs were stimulated with either PHA alone ( $\square$ ) or a combination of PHA and P4 ( $\square$ ). C. Levels of IFN- $\gamma$ mRNA. PBMCs were stimulated with either PHA alone $(\square)$ or a combination of PHA and P4 treated PBMCs $(\square)$. D. Ratio of IFN- $\gamma / \mathrm{IL}-4$ for either PHA alone $\left(\square\right.$ ) or a combination of PHA and $\mathrm{P}_{4}$ treated PBMCs $(\square)$. The IFN- $\gamma / \mathrm{IL}-4$ ratio was calculated as (IFN- $\gamma$ mRNA expression)/(IL-4 mRNA expression). The Low BCS and Control groups contained 20 and 22 cows, respectively. Cytokine mRNA expression was analyzed using heparinised blood. First, $2 \times 10^{6}$ PBMCs were stimulated with PHA for $12 \mathrm{hr}$ at $37^{\circ} \mathrm{C}$. The asterisk indicates a significant difference between the cultures containing PHA alone and the combination of PHA and $\mathrm{P}_{4}$ $(P<0.05$ by Student's $t$-test). The different letters indicate significant differences between the 2 groups $(P<0.05$ by Student's $t$-test). Data are expressed as means \pm S.E. by subclinical ketosis. As $\mathrm{P}_{4}$ suppressed the production of IFN- $\gamma$ in the PBMCs of the normal BCS cows, the reduced responsiveness to the suppressive effect of $\mathrm{P}_{4}$ in the Low BCS cows might be due to already existing systemic immunosuppression.

The target $\mathrm{T}$ cell of $\mathrm{P}_{4}$ was not clarified in the present study. $\mathrm{P}_{4}$ directly suppresses production of IFN- $\gamma$ by naive $\mathrm{CD}^{+} \mathrm{T}$ cells in the mouse [13]. In contrast, $\mathrm{P}_{4}$ inhibits the effector function of activated cytotoxic $\mathrm{T}$ cells in the mouse [12]. Scheibl and Zerbe [23] suggested that progesterone suppresses specific components of the immune system and natural killer (NK) cell activity in cows. These reports suggest that P4 might interfere with several T cells or NK cell activation. As BHB induces inhibitory effects on the proliferation of bovine bone marrow cells in in vitro culture [7], the lymphocyte numbers of the Low BCS cows with higher BHB levels were expected to be lower. The lower responsiveness to $\mathrm{P}_{4}$ in the Low BCS cows might be due to a lower number of circulating lymphocytes, including the target lymphocytes of $\mathrm{P}_{4}$, in the Low BCS group.

In the present study, we also observed that $\mathrm{P}_{4}$ is one of the hormones that suppresses to cellular immune function in dairy cows, but we did not observe this effect in thin cows. The IFN- $\gamma$ expression was hardly suppressed by $\mathrm{P}_{4}$ in the Low BCS cows due to their already existing low levels of IFN- $\gamma$ expression responsiveness. However, it is still unclear whether or not $\mathrm{P}_{4}$ had no effective to immune response in the low $\mathrm{BCS}$ cows. $\mathrm{P}_{4}$ containing medicines are frequently administered in treatment of repeat-breeding cows because high milk yield dairy cows have low progesterone levels during the luteal phase; however the immunosuppressive effect of this steroid hormone should be considered when determining the appropriate treatment [1]. Further studies are needed to clarify the mechanism of the effect of $\mathrm{P}_{4}$ on lymphocyte function in dairy cows in order to maintain their health and prevent mastitis.

ACKNOWLEGEMENTS. Authors are indebted to all experimental farm owners and farm personnel in Aomori Prefecture for their understanding and cooperation.

\section{REFERENCES}

1. Cannon, M.J., Petroff M.G. and Pate, J.L. 2003. Effects of prostaglandin F2alpha and progesterone on the ability of bovine luteal cells to stimulate $\mathrm{T}$ lymphocyte proliferation. Biol. Reprod. 69: 695-700.

2. Chang, B.S., Bohach, G.A., Lee, S., Davis, W.C., Fox, L.K., Ferens, W.A., Seo, K.S., Koo, H.C., Kwon, N.H. and Park, Y.H. 2005. Immunosuppression by T regulatory cells in cows infected with Staphylococcal superantigen. J. Vet. Sci. 6: 247250.

3. Choi, B.C., Polgar, K., Xiao, L. and Hill, J.A. 2000. Progesterone inhibits in-vitro embryotoxic Th1 cytokine production to trophoblast in women with recurrent pregnancy loss. Hum. Reprod. 1: 46-59.

4. Deluyker, H.A., Gay, J.M. and Weaver, L.D. 1993. Interrelationships of somatic cell count, mastitis, and milk yield in a low somatic cell count herd. J. Dairy Sci. 76: 3445-3452. 
5. Dechow, C.D., Rogers, G.W. and Clay, J.S. 2001. Heritabilities and correlations among body condition scores, production traits, and reproductive performance. J. Dairy Sci. 84: 266275.

6. Gearhart, M.A., Curtis, C.R., Erb, H.N., Smith, R.D., Sniffen, C.J., Chase, L.E. and Cooper, M.D. 1990. Relationship of changes in condition score to cow health in Holsteins. J. Dairy Sci. 73: 3132-3140.

7. Hoeben, D., Burvenich, C., Massart-Leen, A.M., Lenjou, M., Nijs, G., Van Bockstaele, D. and Beckers, J.F. 1999. In vitro effect of ketone bodies, glucocorticosteroids and bovine pregnancy-associated glycoprotein on cultures of bone marrow progenitor cells of cows and calves. Vet. Immunol. Immnopathol. 68: 229-240.

8. Kohiruimaki, M., Ohtsuka, H., Hayashi, T., Kimura, K., Masui, M., Ando, T., Watanabe, D. and Kawamura, S. 2006. Evaluation by weight change rate of dairy herd condition. $J$. Vet. Med. Sci. 68: 935-940.

9. Livak, K.J. and Schmittgen, T.D. 2001. Analysis of relative gene expression data using real-time quantitative PCR and the 2(-Delta Delta C(T)) Method. Methods. 25: 402-408.

10. Lydon, J.P., DeMayo, F.J., Funk, C.R., Mani, S.K., Hughes, A.R., Montgomery, Jr. C.A., Shyamala, G., Conneely, O.M. and O’Malley, B.W. 1995. Mice lacking progesterone receptor exhibit pleiotropic reproductive abnormalities. Genes Dev. 9: 2266-2278.

11. Mallard, B.A., Dekkers, J.C., Ireland, M.J., Leslie, K.E., Sharif, S., Lacey, C., Wagter, V.L. and Wilkie, B.N. 1998. Alteration in immune responsiveness during the peripartum period and its ramification on dairy cow and calf health. $J$. Dairy Sci. 81: 585-595.

12. Mannel, D.N., Falk, W. and Yron, I. 1990. Inhibition of murine cytotoxic T cell responses by progesterone. Immunol. Lett. 26: 89-94.

13. Miyaura, H. and Iwata, M. 2002. Direct and Indirect Inhibition of Th1 Development by Progesterone and Glucocorticoids. $J$. Immunol. 168: 1087-1094.

14. Ohtsuka, H., Watanabe, C., Kohiruimaki, M., Ando, T., Watanabe, D., Masui, M., Hayashi, T., Abe, R., Koiwa, M., Sato, S. and Kawamura, S. 2006. Compare to Changes in Peripheral Blood Mononuclear Cell in Periparturient Dairy Cows between Two Different Nutritive Condition. J. Vet. Med. Sci. 68: 1161-1166.

15. Patton, J., Kenny, D.A., McNamara, S., Mee, J.F., O'Mara,
F.P., Diskin, M.G. and Murphy, J.J. 2007. Relationships among milk production, energy balance, plasma analytes, and reproduction in Holstein-Friesian cows. J. Dairy Sci. 90: 649658.

16. Pires, J., Curi, R. and Otton, R. 2007. Induction of apoptosis in rat lymphocytes by starvation. Clin. Sci. 112: 59-67.

17. Price, S.J., Sopp, P., Howard, C.J. and Hope, J.C. 2007. Workshop cluster 1+ gamma/delta T-cell receptor T cells from calves express high levels of interferon-gamma in response to stimulation with interleukin-12 and -18. Immunology 120: 5765.

18. Reksen, O., Havrevoll, O., Grohn, Y.T., Bolstad, T., Waldmann, A. and Ropstad, E. 2002. Relationships among body condition score, milk constituents, and postpartum luteal function in Norwegian dairy cows. J. Dairy Sci. 85: 1406-1415.

19. Riollet, C., Rainard, P. and Poutrel, B. 2001. Cell subpopulations and cytokine expression in cow milk in response to chronic Staphylococcus aureus infection. J. Dairy Sci. 84: 1077-1084.

20. Roche, J.F. 2006. Relationships among international body condition scoring systems. Anim. Reprod. Sci. 96: 282-296.

21. Ruegg, P.L. and Milton, R.L. 1995. Body condition scores of Holstein cows on Prince Edward Island; relationships with yield, reproductive performance, and disease. J. Dairy Sci. 78: 552-564.

22. Sato, S., Suzuki, T. and Okada, K. 1995. Suppression of mitogenic response of bovine peripheral blood lymphocytes by ketone bodies. J. Vet. Med. Sci. 57: 183-185.

23. Scheibl, P. and Zerbe, H. 2000. Effect of progesterone on the immune system in consideration of bovine placental retention. Dtsch Tierarztl Wochenschr. 107: 221-217.

24. Stites, D.P. and Siiteri, P.K. 1983. Steroids as immunosuppressants in pregnancy. Immunol. Rev. 75: 117-138.

25. Szekeres-Bartho, J. and Wegmann, T.G. 1996. A progesteronedependent immunomodulatory protein alters the Th1/Th2 balance. J. Reprod. Immunol. 31: 81-95.

26. Watanabe, C., Ohtsuka, H., Kohiruimaki, M., Tokita, M., Terasawa, S., Ando, T., Watanabe, D. and Sato, S. 2007. Utility of Immunity Profile to Dairy Herds during Peripaturient Periods. J. Jpn. Vet. Med. Assoc. 60: 709-714.

27. Yaqoob, P. and Calder, P.C. 1995. The effects of dietary lipid manipulation on the production of murine T cell-derived cytokines. Cytokine 7: 548-553. 